\title{
Zarys historii przemian topograficznych przykościelnej części Spycimierza (gmina Uniejów)
}

STRESZCZENIE | Celem prezentowanego opracowania jest próba nakreślenia charakteru przemian przestrzennych, zachodzących na przestrzeni wieków w obrębie posesji zlokalizowanych na wprost kościoła (dz. nr ewid. 406), poprzedzających ostateczne uformowanie współczesnego zagospodarowania tego obszaru. Poniższe ustalenia mają charakter wprowadzający do mających miejsce w 202I r. ratowniczych badań archeologicznych, które odbywały się przed rozpoczęciem budowy Centrum Historyczno-Kulturalnego „Spycimierskie Boże Ciało”, obejmującej północną część posesji oznaczonej na poniższej mapie jako „obszar inwestycji”. Przedstawienie wniosków, które mogłyby znaleźć zastosowanie w prowadzonych na określonym obszarze pracach archeologicznych wymagało jak najpełniejszego rozpoznania zasobu materiałów źródłowych, ale również dokonania ich znaczącej selekcji. W ramach podsumowania przeprowadzono syntezę zgromadzonych informacji oraz zaproponowano periodyzację przemian topograficznych analizowanego obszaru, wydzielając pięć faz chronologicznych

SŁOWA KLUCZOWE | Spycimierz, gmina Uniejów, Boże Ciało, badania archeologiczne

\section{Zagadnienia wstępne}

Spycimierz - miejscowość położona nad rzeką Siekiernik (dawną odnogą Warty), w niewielkiej odległości od Uniejowa, przed wiekami stanowił ważny ośrodek książęcej administracji i rozbudowany kompleks osadniczy, złożony z kasztelańskiego grodu i rozwijającej się w XI-XII w. osady

\footnotetext{
*Michał Szymański, Uniwersytet Łódzki, Instytut Archeologii; e-mail: mszymanskiı3@ wp.pl, https://orcid.org/o000-0002-50I0-8568

** Jakub Śliwiński, Firma Archeologiczna ALTAMIRA; e-mail: altamira.archeo@onet.pl
} 
targowej. Mimo niewątpliwych walorów historycznych oraz urbanistycznych (ruralistycznych) historia rozwoju przestrzennego Spycimierza wciąż skrywa wiele tajemnic, wyjawianych stopniowo dzięki zainteresowaniu ze strony naukowców oraz badaniom zlecanym w związku z podejmowanymi inwestycjami.

Celem prezentowanego opracowania jest próba nakreślenia charakteru przemian przestrzennych, zachodzących w poprzednich stuleciach w obrębie posesji zlokalizowanych na wprost kościoła (nr ewid. działki 406), poprzedzających ostateczne określenie współczesnego zagospodarowania tego obszaru. Poniższe ustalenia mają charakter wprowadzający do mających miejsce w 202I r. ratowniczych badań archeologicznych, które prowadzono przed rozpoczęciem budowy Centrum Historyczno-Kulturalnego „Spycimierskie Boże Ciało", obejmującej północną część posesji oznaczonej na poniższej mapie jako „obszar inwestycji”.

Przedstawienie wniosków, które mogłyby znaleźć zastosowanie w prowadzonych na określonym obszarze pracach archeologicznych wymagało jak najpełniejszego rozpoznania zasobu materiałów źródłowych, ale również dokonania ich znaczącej selekcji. Wykorzystano istniejące już opracowania historyczne, a także materiały źródłowe przechowywane w archiwach oraz zdigitalizowane na platformach cyfrowych. Na nowo przestudiowano zapisy zgromadzone w Kodeksie Dyplomatycznym Wielkopolski, odczytane przez mgr. Zdzisława Koczarskiego (IJP PAN)․ Analizie poddano również dokumenty rządowe z początku XIX w., udostępniane na platformach cyfrowych. Zapoznano się ponadto z archiwaliami przechowywanymi w Archiwum Narodowym w Krakowie oraz w Archiwach Państwowych w Kaliszu i Łodzi - oddział w Sieradzu.

Kluczowe znaczenie w kontekście studiów nad przestrzenią Spycimierza mają mapy archiwalne. Większość zabytków kartografii ze względu na zastosowaną skalę przedstawia miejscowość jedynie na tle sieci głównych dróg oraz osiedli². Mimo zasadniczych powiązań rozplanowania osady

\footnotetext{
I Kodeks Dyplomatyczny Wielkopolski, dalej: KDW, seria I, I/II, II.

2 Przykładowo: K. de Perthées, Mapa szczególna województwa łęczyckiego, I793 r. (AGAD, AK 96, Zb. SA I2); D. Gilly, Spezialkarte von Südpreussen, I8I3; J. Kolberg, Atlas Królestwa Polskiego, Warszawa 1827 (Biblioteka Narodowa, polona.pl); mapy drukowane: Übersichtskarte von Mitteleuropa I893 B, Piotrków Q52, (1909 r.), K. Nakęski, Mapa Królestwa Polskiego z oznaczeniem miast, osad, wsi, komór, kolei, dróg bitych, traktów pocztowych i rzek (1913 r.), Mapa Administracyjna Rzeczypospolitej Polskiej I:300 ooo, ark. 24 (64), 1937 r.
} 


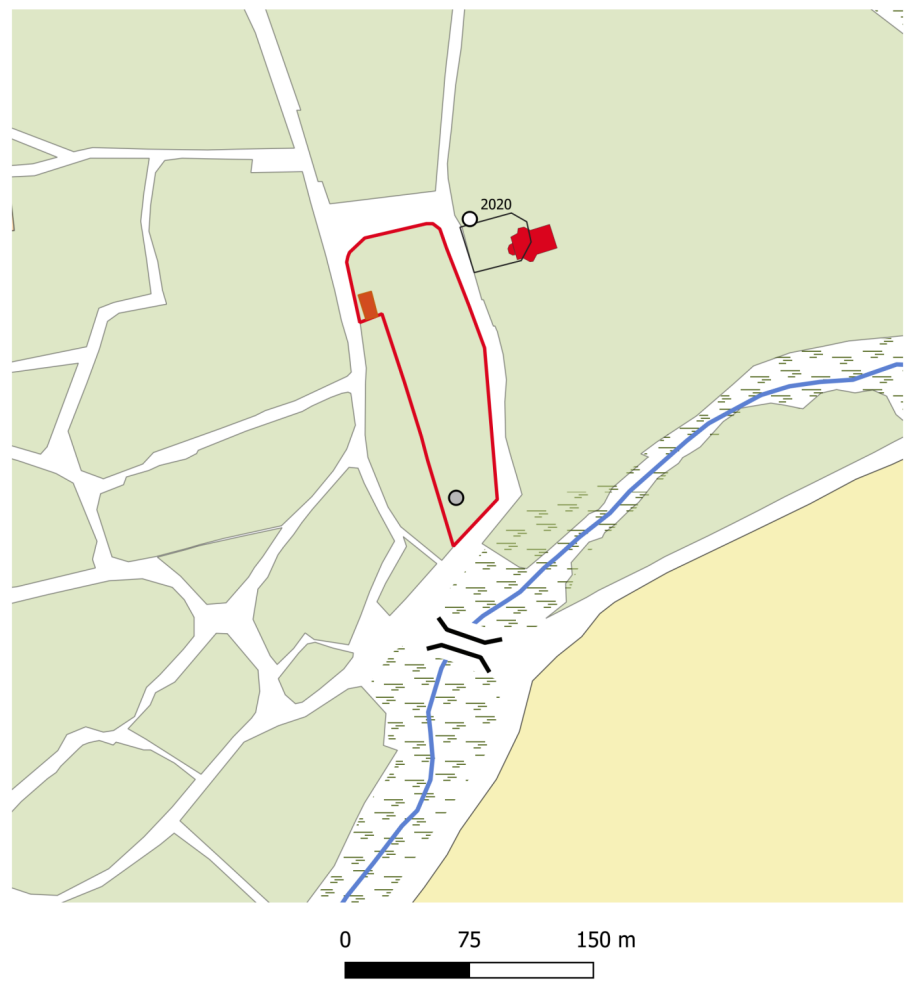

Lokalizacja obszaru badań w Spycimierzu

$\begin{array}{ll}\text { J Rzeka } & \square \text { Obszar inwestycji (dz. nr ewid. 406) } \\ \text { J } \text { Most } & \square \text { Zarys działki dawnego kościoła } \\ \text { O Lokalizacja badań archeo- } & \square \text { Bloki parcel wiejskich } \\ \text { logicznych w obrębie wsi } & \square \text { Cmentarz } \\ \text { O } \begin{array}{l}\text { Bunkier z czasów } \\ \text { drugiej wojny światowej }\end{array} \\ \begin{array}{l}\text { Kościół katolicki } \\ \text { Budynek szkoły z lat 30. XX w. }\end{array}\end{array}$

Ryc. I. Lokalizacja badanego obszaru w Spycimierzu

z przebiegiem łączących się w niej traktów dalekosiężnych po przeanalizowaniu map tego rodzaju nie poczyniono spostrzeżeń bezpośrednio związanych z głównym problemem badawczym: układem parcelacji wewnątrz wsi. Z tego względu zdecydowano się oprzeć na mapach o większej skali, poczynając od I:50 ooo (mapa Gilly'ego z I793 r. - zbiory Staatsbibliothek zu Berlin). Istotnych informacji dotyczących przemian przestrzeni Spycimierza w XIX w. dostarczyły mapy z lat I804, I845 (odrys z I86I r.) i i847, przechowywane w Archiwum Głównym Akt Dawnych. Dla potwierdzenia wniosków wysuniętych z analizy map przestrzeni wsi 
w XIX w. wykorzystane mogą być mapy topograficzne z XIX ${ }^{3}$ i XX w. ${ }^{4}$ oraz współczesne mapy ewidencyjnes. Jako że w analizowanej części wsi dokumentują one układ przestrzenny utrzymujący się w dużej mierze do dnia dzisiejszego, nie włączono ich kompletu do treści niniejszego opracowania.

W kolejnych częściach opracowania przedstawiono zarys dziejów miejscowości, opierając się na istniejącej literaturze oraz materiale źródłowym, a także przegląd dotychczasowych badań archeologicznych dotyczących omawianej miejscowości. Główną część pracy stanowi analiza źródeł kartograficznych, wsparta pozostałymi informacjami archiwalnymi. W ramach podsumowania przeprowadzono syntezę zgromadzonych informacji oraz zaproponowano periodyzację przemian topograficznych analizowanego obszaru, wydzielając pięć faz chronologicznych.

\section{Zarys dziejów miejscowości}

Według legendy przedstawionej w XVI w. w herbarzu Bartosza Paprockiego założycielem Spycimierza miał być Spycimir, protoplasta małopolskiego rodu Leliwitów, który przekazał następnie ten majątek (lub jego część) arcybiskupom gnieźnieńskim. Informacje zawarte w XVI-wiecznym przekazie mają jednak niepotwierdzony, a co za tym idzie - legendarny charakter ${ }^{6}$.

Pierwsze zapisy historyczne na temat Spycimierza pochodzą z przełomu XI i XII w. W dokumencie z I065 r., będącym jednak zapewne falsyfikatem z XII w., potwierdzono opłaty odprowadzane z kościoła w Spycimierzu na rzecz klasztoru w Mogilnie. Ze Spycimierza pobierano wówczas 7 grzywien - podobnie jak z Rozprzy, kolejnego ośrodka grodowego i późniejszej kasztelanii; mniejsze opłaty pobierano z Wolborza

3 Przede wszystkim Mapa Kwatermistrzostwa, ark. Io, kol. II, sek. IV, Łęczyca I843 r. 4 Mapa Szczegółowa Polski, Oberkommando des Heeres, P4I S27 C (4I27 C)

Brückstädt (Unjejow), AMS M75I, M753 Poland, M752 East Prussia I:50 ooo, 292I IV Uniejów (1963 r.)

5 Między innymi: Mapa ewidencyjna Spycimierza, lata 6o. XX w., Wydział Geodezji, Kartografii i Gospodarki Nieruchomościami - Starostwo Powiatowe w Poddębicach; współczesną mapę ewidencyjną pobrano z portalu Geoportal.

6 Herby rycerstwa polskiego przez Bartosza Paprockiego zebrane i wydane r. p. I584, wyd. K.J. Turowski, Kraków I858 (udostępnione w Wielkopolskiej Bibliotece Cyfrowej https://www.wbc.poznan.pl/dlibra/publication/3II64/edition/48455/content); T. Figlus, Rozwój układu ruralistycznego Spycimierza na tle dziejów osadnictwa w świetle badań geograficzno-historycznych $i$ archeologicznych, „Biuletyn Uniejowski” 20I5, t. 4, s. 77. 
i Żarnowa, większe - z Łęczycy7. Spycimierz pojawia się również w kronice Galla Anonima z początku XII w. w kontekście opisu konfliktu między Bolesławem Krzywoustym i jego bratem Zbigniewem. Zgodnie z przekazem Bolesław pojmał nieopodal Spycimierza arcybiskupa Marcina. Hierarcha ten przebywał w spycimierskiej parafii i udzielał spowiedzi, gdy doszło do napaści Pomorzan w IIo7 r. ${ }^{8}$ W II36 r. w bulli Innocentego II potwierdzono natomiast należności odprowadzane z parafii w Spycimierzu na rzecz diecezji gnieźnieńskiej, wymieniając przy tym Spycimierz jako stolicę jednej z kasztelanii. Z miejscowości położonych dookoła Spycimierza pobierano dziesięciny - były to Janowice, Tądów, Smulsko, Przykona, Turkowice, Turek, Uniejów, Charchów, Klonów, Gażowo i Miłostowice?. W administracji kościelnej Spycimierz należał do archidiakonatu uniejowskiego archidiecezji gnieźnieńskiej ${ }^{\text {to }}$.

W tym okresie w Spycimierzu działał już gród o funkcjach obronnych oraz administracyjnych, a także związana z nim osada otwarta ${ }^{\text {II }}$. Istotne źródło dochodów dla grodu stanowiła komora celna. Dobrą koniunkturę ośrodka, czerpiącego zyski z kontroli szlaku handlowego łączącego północ z południem (szlak morawsko-pomorski), osłabiła pod koniec XIII w. lokacja miejska arcybiskupiego Uniejowa (przed I 290 r.), położonego zresztą na terenie kasztelanii spycimierskiej. Wcześniej najbliżej położonymi miastami lokacyjnymi były Warta, oddalona o ponad $30 \mathrm{~km}$ (mniej więcej I dzień drogi) na południe, oraz Łęczyca - zlokalizowana w podobnej odległości na wschodzie. Na zachodzie najbliżej znajdowały się miejscowości Kalisz oraz Konin. Wszystkie te ośrodki otrzymały prawa miejskie mniej więcej w połowie XIII w. Dopiero na przełomie XIV-XV w. praw miejskich doczekały się inne bliższe ośrodki, takie jak: Turek, Dobra, Poddębice i Dąbie. Akt lokacyjny zapewniał miastu dodatkowe przywileje handlowe, marginalizując gospodarcze znaczenie stolicy kasztelanii.

7 Kodeks Dyplomatyczny Wielkopolski (dalej: KDW) seria I, nr 3.

8 S. Zajączkowski, S.M. Zajączkowski, Materiały do stownika geograficzno-historycznego dawnych ziem tęczyckiej i sieradzkiej do I400 roku, cz. II, Łódź I970, s. II2-II3; Gall Anonim, Cronica et gesta ducum sive principum Polonorum, wyd. K. Maleczyński, Kraków 1952, s. I08.

9 KDW I, 7.

Io S. Zajączkowski, S.M. Zajączkowski, dz. cyt., s. II2-II3; Atlas Fontium.

II T. Poklewski, Spicymierska włość grodowa w średniowieczu. Obraz gospodarczy, Łódź 1975, s. 17-27. 
Od pierwszych dziesięcioleci XIII stulecia w źródłach pisanych coraz częściej pojawiają się kasztelanowie spycimierscy, wymieniani z imienia. W I247 r. kasztelan spycimierski Bogus wystąpił jako świadek donacji ${ }^{12}$, w I252 r. donację dziesięcin potwierdzał kasztelan Stresko ${ }^{\text {I3 }}$.

W I33 I r. Spycimierz został spustoszony przez Krzyżaków podczas jesiennej rejzy, która doprowadziła do ogromnych zniszczeń nizinnej części Królestwa Polskiego. Polska strona konfliktu praktycznie nie prowadziła zakrojonych na dużą skalę działań zbrojnych, a wiele miast i grodów padło łatwym łupem błyskawicznie przeprowadzonych napadów. Wynikało to z niedużej liczebności załóg pozostawionych w obiektach obronnych oraz z niewielkiej przydatności militarnej anachronicznych umocnień drewniano-ziemnych wobec nowoczesnej sztuki wojennej udoskonalonej przez zakon krzyżacki. Ostatecznie powracające wojska krzyżackie zostały częściowo rozgromione podczas bitwy pod Płowcami.

W 1347 r. król Kazimierz Wielki przekazał Spycimierz arcybiskupowi gnieźnieńskiemu. W tym okresie Spycimierz określono terminem oppidum, odnoszącym się do osad o miejskim charakterze ${ }^{14}$. Użycie tego określenia ma jednak charakter jednorazowy. Może ono świadczyć o podjętej wówczas próbie nadania Spycimierzowi praw miejskich - zapewne nieudanej i nieniosącej ze sobą zmian przestrzennych - lub też o chęci podkreślenia istotnych funkcji targowych spełnianych przez Spycimierz. Zdaniem części badaczy Spycimierz mógł jednak funkcjonować jako osada o prawach miejskich nawet do końca XV w. ${ }^{15}$

Arcybiskup gnieźnieński Jarosław Bogoria Skotnicki uparcie dążył do odbudowy dóbr zniszczonych w I33 I r. Zarządzał wówczas posiadłościami w okolicach Uniejowa, a zatem w drugiej połowie XIV w. niejednokrotnie przebywał również w spycimierskim majątku. W dniu I2 sierpnia I358 r. dopełnił tam formalności związanych z zamianą dóbr i kościołów dokonaną między królem Kazimierzem oraz klasztorem kanoników regularnych na wrocławskim Piasku' ${ }^{16}$.

\footnotetext{
I2 KDW I, nr 267.

I3 KDW I, nr 304.

I4 KDW II, nr I354.

I5 M. Kulesza, Morfogeneza miast na obszarze Polski Środkowej w okresie przedrozbiorowym. Dawne województwa tęczyckie i sieradzkie, Łódź 200I, s. 47, 256.

I6 KDW II, nr 1734 .
} 
Przejście spycimierskiego majątku w ręce arcybiskupie nie doprowadziło do likwidacji kasztelanii, choć całkowicie zmieniło jej charakter. Nie była ona już jednostką administracyjną o istotnym znaczeniu, zwłaszcza od momentu utworzenia powiatów (Spycimierz oraz Uniejów weszły wówczas w skład powiatu szadkowskiego w województwie sieradzkim) ${ }^{17}$. Kasztelanowie w strukturze późnośredniowiecznego oraz nowożytnego społeczeństwa przetrwali jako prestiżowy urząd zapewniający znaczne wpływy polityczne (w czasach Rzeczypospolitej Obojga Narodów kasztelanowie wchodzili w skład senatu). Znani są zatem liczni kasztelanowie spicymierscy z XIV-XVIII w. Podpisując się jako urzędnicy, sygnowali dokumenty, potwierdzali ich autentyczność oraz występowali w charakterze świadków. Niejednokrotnie reprezentowali przy tym arcybiskupów gnieźnieńskich ${ }^{18}$.

W późnym średniowieczu w Spycimierzu zintensyfikowano produkcję rolną, obejmując uprawami dotychczasowe nieużytki. Ponad bagnistym brzegiem Warty miał prowadzić do Spycimierza szeroki, moszczony faszyną i umocniony belkami szlak przecinający bagniste łąki, na dogodniejszym obszarze przechodzący w drogę polną ${ }^{19}$. Udokumentowany trakt był prawdopodobnie fragmentem drogi biegnącej przez miasto Wartę z Sieradza do Uniejowa, lokalizowanej po prawej stronie rzeki. Od XIV w. wzrosło zresztą jej znaczenie ${ }^{20}$. Związek z przebiegiem szlaków komunikacyjnych mogły mieć również groble młynów wodnych, funkcjonujących zarówno w Spycimierzu, jak i w jego najbliższych okolicach. Ograniczały one zapewne możliwość spławu rzecznego, prężnie rozwijającego się w dorzeczu Odry od XIV w., a w obrębie koryta Warty obejmującego najprawdopodobniej również okolice Uniejowa.

Intensywniejsze użytkowanie terenów rolnych doprowadziło do konieczności precyzyjniejszego wyznaczenia granic między poszczególnymi

I7 R. Rosin, S.M. Zajączkowski, Osadnictwo i stosunki wtasnościowe sieradzkiego na przetomie późnego średniowiecza i czasów nowożytnych, [w:] T.J. Horbacz, L. Kajzer (red.), Między pótnocą a południem. Sieradzkie i wieluńskie w późnym średniowieczu i czasach nowożytnych. Materiały z sesji naukowej w Kościerzynie koło Sieradza (4-6 grudnia I99I r.), Sieradz I993, s. 3I-33; H. Rutkowski, Granice państwowych jednostek terytorialnych, [w:] Atlas Historyczny Polski. Województwo sieradzkie i województwo tęczyckie $w$ drugiej połowie XVI wieku, cz. II, Komentarz, indeksy, Warszawa I998, s. 26-29. I8 M.in. KDW I, nr 267, 304, 859; II, nr I323, I438, I472, I620.

I9 T. Poklewski, Spicymierska wtość..., s. 62, 92-99.

20 R. Rosin, Warunki naturalne, drogi lądowe i rozwój terytorialno-administracyjny, [w:] J. Śmiałowski (red.), Szkice z dziejów Sieradzkiego, Łódź 1977, s. 22. 
majątkami ziemskimi. W I429 r. sąd grodzki w Sieradzu uregulował przebieg granicy między Spycimierzem a Dąbrowicą, posiadłością Jana Grabskiego z Dobrej, na rzece Gosznicy ${ }^{21}$. W korycie rzeki umieszczone zostały wówczas graniczne pale drewniane, oddzielające strefy wód dostępne dla mieszkańców każdego z majątków. Znakiem granicznym był kopiec, usypany przez Jana Grabskiego „naprzeciwko lasu Mniszek” (w późniejszym okresie był to przysiółek, położony na południowy zachód od Spycimierza), w którego pobliżu znajdował się również młyn należący do Grabskiego oraz związana z nim grobla. Aby uniemożliwić przejazd wozów groblą (i naruszenie granicy), na krańcu grobli nakazano usypać rozległy kopiec, tak aby Jan mógł „ze swojego brzegu przez groblę jechać konno, kiedy będzie tego potrzebował, na ile rozciąga się jego pole”. Poddani z Dąbrowicy nie mogli korzystać z drzew lasu Mniszek ani pozyskiwać tam ziemi do wzmacniania nasypów ${ }^{22}$.

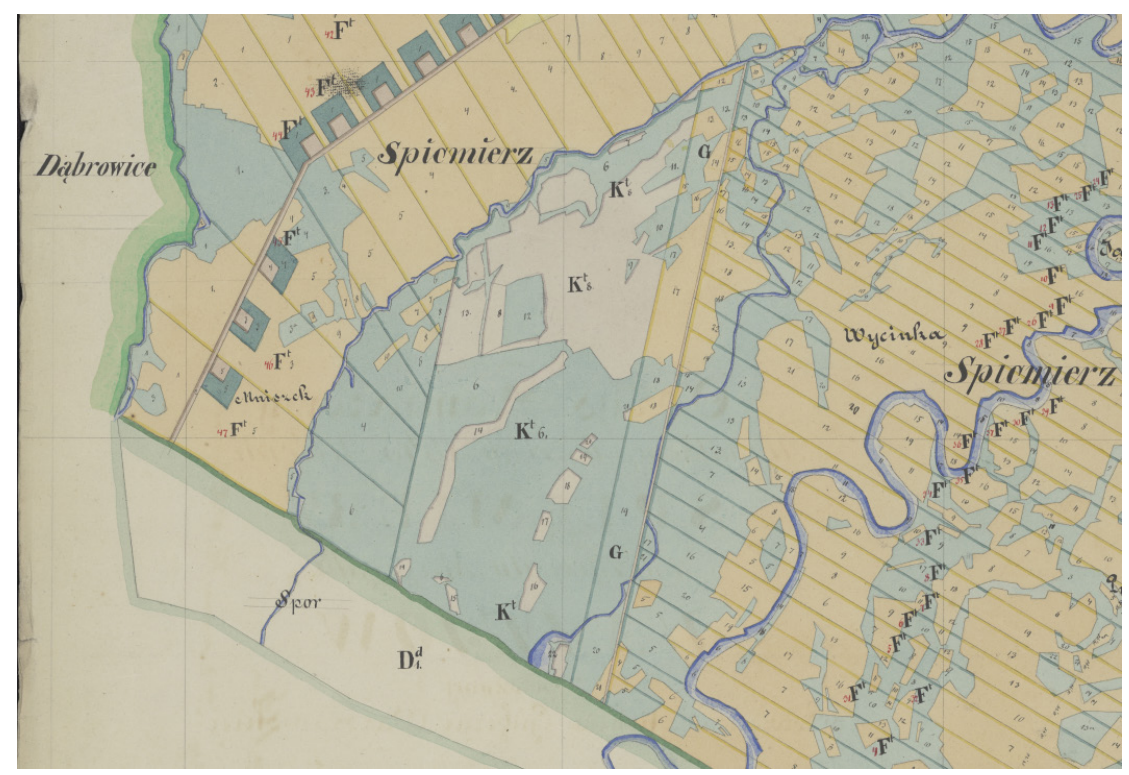

Ryc. 2. Południowo-zachodnia granica majątku Spycimierz na sporządzonym w I86I r. odrysie mapy regulacyjnej z I845 r.

Plan pomiarowy kolonii Spicymierz (I86I r.), AGAD - Zbiór Kartograficzny 204-I5

2I A. Szymczakowa, Nobiles Siradienses. Rody Porajów, Pomianów, Gryfów, Kopaczów i Pobogów, Łódź 20II, s. II5.

22 KDW II nr 492, tłum. mgr Zdzisław Koczarski (IJP PAN). 
Intensyfikacja rolnictwa, dostrzeżona przez A. Nadolskiego i T. Poklewskiego-Koziełl, łączyła się zapewne z procesami rozwoju gospodarki folwarcznej oraz próbami związania chłopów z zamieszkiwaną przez nich ziemią. Jednocześnie brak informacji o dynamicznym rozwoju demograficznym majątku w tym okresie ${ }^{23}$. W I485 r. Beata z Borzewiska, posiadaczka dóbr w Borzewisku, procesowała się z arcybiskupem gnieźnieńskim Zbigniewem Oleśnickim w sprawie chłopa Stanisława (zwanego Kozieł) ze Spycimierza, któremu zarządcy spycimierskiego majątku uniemożliwiali przeniesienie się do Borzewiska ${ }^{24}$.

W I49I r. Zbigniew Oleśnicki przekazał parafię spycimierską (czerpiącą dochody z własnego folwarku oraz z pracy zamieszkałych we wsi rybaków) na rzecz uposażenia kolegium mansjonarskiemu utworzonemu przy kolegiacie w Uniejowie. Parafia obejmowała Spycimierz, Człopy oraz folwark Zieleń.

W I5I2 r. w Spycimierzu znajdowało się 7 łanów ziemi, w tym 4 zasiedlone przez kmieci, oraz młyn Golen. W tym okresie we wsi mieszkało 2 zagrodników i I4 rybaków, użytkujących niewielkie działki i role, zobligowanych (poza opłatami czynszowymi) do daniny z trzech korców chmie$\mathrm{lu}^{25}$. W połowie XVI w. w Spycimierzu użytkowanych było już 6 łanów, funkcjonowały również młyn o nazwie Malczewski oraz karczma. W XVIXVIII w. poszczególne grunty położone w obrębie Spycimierza były oddawane w dzierżawę, niekiedy dokonywano również ich sprzedaży ${ }^{26}$.

W I7I2 r. wymieniono uposażenie parafii (rola, 2 ogrody położone nad rzeką i 4 łąki). W I728 r. parafia liczyła zaledwie 200 dusz. W latach 80. XVIII w. wybudowany został drewniany kościół (w miejscu poprzedniego, poddanego rozbiórce) ${ }^{27}$. Według taryfy podymnego z 1775 r. w Spycimierzu w tym okresie znajdowało się 30 zamieszkiwanych domostw ${ }^{28}$.

23 T. Poklewski, Spicymierska wtość..., s. 49-58; A. Nadolski, Spicymierz nad Warta, średniowieczny zespót osadniczy, „Archeologia Polski” 1966, t. I0, z. 2, s. 70I-7I2.

24 A. Szymczakowa, Nobiles..., s. 237.

25 T. Figlus, Rozwój uktadu..., s. 79.

26 Archiwum Narodowe w Krakowie: Zbiór Zygmunta Glogera 2/233.

27 T. Figlus, Rozwój układu..., s. 8o; T. Grabarczyk, A. Kowalska-Pietrzak, J. Szymczak, Uniejowskie strony: karty z przeszłości odległej, nieznanej i bliskiej gminy Uniejów, Łódź-Uniejów 2008, s. I34.

28 Taryfa podymnego z 1775 r., Verzeichnißaller adelichen, geistlichen und königlichen Oertern in Polen, nach den Woiwodschaften und Districten, und mit Bemerkung der Anzahl der Rauchfänge in jedem Orte, „Magazin für die neue Historie und Geographie” I788, t. 22 
Po 1793 r. dobra uniejowskie weszły w skład zaboru pruskiego, w 1796 r. doprowadzono do ich sekularyzacji i stały się one tym samym własnością państwa. W I8I5 r. omawiany obszar został przeniesiony do zaboru rosyjskiego. W tym okresie w Spycimierzu, podobnie jak w całej Polsce, obserwowany jest niewielki wzrost demograficzny; w I827 r. znajdowało się w nim 50 zamieszkanych domostw, a liczba mieszkańców wynosiła 434 osoby $^{29}$.

Od I836 r. dobra uniejowskie zostały przekazane carskiemu generałowi Karolowi Tollowi oraz jego spadkobiercom. Rodzina ta posiadała majątek aż do odzyskania przez Polskę niepodległości. W I864 r. przeprowadzono uwłaszczenie włościan, regulując przy tym grunty i w pewnym stopniu modyfikując układ miejscowości ${ }^{30}$. W I890 r. w Spycimierzu i Malczewie znajdowało się 7I domostw przy zaludnieniu wynoszącym 535 osób ${ }^{31}$. W XIX w. w miejscowości były trzy mosty, zapewniające mieszkańcom dostęp do pól, położonych po obu stronach rzeki ${ }^{32}$.

W xx w. wzniesiono trwałą zabudowę, częściowo zachowaną do dzisiaj. W latach 30. XX w. wybudowane zostały strażnica ochotniczej straży pożarnej oraz budynek szkoły. W latach 1937 i 197I doszło do dużych pożarów, w wyniku których spłonęła znaczna część zabudowy oraz pamiątek i dokumentów dotyczących przeszłości wsi i jej mieszkańców. W I97I r. spłonęły 64 gospodarstwa. W okresie powojennym usypano wał przeciwpowodziowy, zaś w latach 1986-1992 wybudowano dzisiejszy kościół parafialny, zastępując nim drewniany obiekt wzniesiony po drugiej wojnie światowej w miejscu XVIII-wiecznej świątyni rozebranej przez Niemców ${ }^{33}$. Dzisiejsza bryła kościoła została cofnięta w stosunku

[online] https://books.google.pl/books?id=X4lOAAAAcAAJ\&printsec=frontco$\mathrm{ver} \& \mathrm{hl}=\mathrm{pl}$ v=onepage\&q\&f=false [dostęp: $20.03 .202 \mathrm{I}]$.

29 J. Wąsicki, Ziemie polskie pod zaborem pruskim. Prusy Południowe 1793-I806, Studium historyczno-prawne, Wrocław 1957; Tabela miast, wsi, osad Królestwa Polskiego z wyrażeniem ich położenia i ludności alfabetycznie ułożona w Biurze Komisji Rzadowej Spraw Wewnętrznych i Policji, t. 2, Warszawa 1827, s. I89 [online] https://www.wbc.poznan.pl/dlibra/show-content/publication/ edition/IIOII7?id=IIOII7 [dostęp: 20.03.202I].

30 T. Figlus, Rozwój uktadu..., s. 8o.

3I B. Chlebowski, F. Sulimierski, W. Walewski, Stownik Geograficzny Królestwa Polskiego i innych krajów stowiańskich, t. II, Warszawa 1890, s. I09.

32 Tamże.

33 T. Figlus, Rozwój układu..., s. 80. 
do wcześniejszej budowli, znajdującej się bliżej drogi. Jest to widoczne we współczesnych podziałach katastralnych, w których do dziś wydzielona pozostaje działka po dawnym kościele (nr ewid. I056).

\section{Dotychczasowe badania archeologiczne}

Już w XIX w. wzmiankowano częste w Spycimierzu odkrycia grobów popielnicowych ${ }^{34}$. W sąsiedztwie wsi zarejestrowano fragmenty ceramiki neolitycznej, reprezentującej wytwórczość społeczności kultury pucharów lejkowatych, a także cmentarzyska popielnicowe z epoki żelaza: cmentarzysko kultury łużyckiej związane z okresem halsztackim oraz kultury przeworskiej (okres wpływów rzymskich) ${ }^{35}$.

Szczególnym zainteresowaniem badaczy cieszyło się położone w dolinie rzecznej grodzisko. Stanowisko było powszechnie znane od stuleci, a jego funkcja nie odeszła w zapomnienie: relikty grodu przez setki lat funkcjonowały pod nazwą „Kasztelania”, odnotowaną również na mapach z XIX w. ${ }^{36}$ Badaniami powierzchniowymi teren grodziska objęto w latach 1923 (R. Jakimowicz) i I935 (J. Skoiński) 37. W I949 r. prace te kontynuowała J. Kamińska ${ }^{38}$. W latach 1962-1963 badania archeologiczne, obejmujące prace wykopaliskowe, prowadził A. Nadolski ${ }^{39}$. W 2014 i 2016 r. na terenie grodziska nieinwazyjne badania archeologiczne przeprowadzili badacze pod kierownictwem J. Sikory, wykonując prospekcję magnetyczną i elektrooporową oraz badania powierzchniowe ${ }^{40}$. Dzięki temu udało się określić chronologię przekształceń grodziska, rozwijającego

34 B. Chlebowski, F. Sulimierski, W. Walewski, dz. cyt., s. Io9.

35 W. Różańska, Cmentarzysko tużyckie z młodszego okresu halsztackiego w Spicimierzu, pow. Turek, „Materiały Starożytne” 1958, t. IV, s. I45-I56; A. Kietlińska, T. Dąbrowska, Cmentarzysko z okresu wpływów rzymskich we wsi Spicimierz, pow. Turek, „Materiały Starożytne" 1963, t. IX, s. I43-252.

36 Plan wsi Spicymierz w ekonomii Uniejów (I804 r.), AGAD - Zbiór Kartograficzny, 344-4. 37 R. Jakimowicz, Sprawozdanie z działalności Państwowego Konserwatora Zabytków Przedhistorycznych Okręgu Warszawskiego za rok 1923, „Wiadomości Archeologiczne” 1925, t. IX, z. 3-4, s. 329; J. Skoiński, Spicimierz. Gród i kasztelania. Szkic historyczny, Łódź 1936.

38 J. Kamińska, Grody wczesnośredniowieczne ziem Polski środkowej na tle osadnictwa, „Acta Archaeologica Universitatis Lodziensis” 1953, nr 2, s. I08-IIO.

39 A. Nadolski, Spicymierz nad Wartą, średniowieczny zespót osadniczy, „Archeologia Polski” I966, t. IO, z. 2, s. 70I-7I2.

40 J. Sikora, Grodziska wczesnośredniowieczne Polski Centralnej. Archeologiczne badania nieinwazyjne z lat 2013-2016, Łódź 2017, s. 193-210. 
się od przełomu XI/XII w. do poł. XIII w., zniszczonego w wyniku działań zbrojnych w I33I r., a następnie przekształconego w grodzisko stożkowate, które ostatecznie zanikło w okresie nowożytnym. Najliczniejszy materiał zabytkowy zebrany na terenie grodziska pochodzi z przełomu XI/XII w. oraz z XIII w., w kolejnych fazach ilość materiału ulega wyraźnie zmniejszeniu. Badania nie wykazały obecności rozwiniętego osadnictwa otwartego sąsiadującego bezpośrednio z grodem, pośrednio potwierdzając pierwotny charakter osady funkcjonującej w miejscu dzisiejszej wsi.

W latach 6o. oraz 70. XX w. zróżnicowanym, szeroko zakrojonym pracom badawczym poddano okoliczne miejscowości, tworząc wstępny obraz rozwoju wczesnośredniowiecznego osadnictwa sięgającego VIII w. (miejscowość Dębowe Górki). Na podstawie tych badań zaproponowano później szereg interpretacji dotyczących rytmu rozwoju zagospodarowania terenów uprawnych, związanych ze Spycimierzem ${ }^{4}$.

W 2020 r. Wojewódzki Urząd Ochrony Zabytków poinformował o zamiarze włączenia historycznego układu przestrzennego Spycimierza, jako zabytku archeologicznego lądowego, do wojewódzkiej ewidencji zabytków nieruchomych $^{42}$. W 2020 r. Z. Rybacki i A. Nierychlewska przeprowadzili badania archeologiczne po zewnętrznej stronie ogrodzenia otaczającego kościól, odkrywając związane z cmentarzem przykościelnym pochówki szkieletowe oraz jamy z kośćmi zwierzęcymi. Znaleziska datowane są na XII-XIII w. (jeden ze szkieletów zaopatrzony był w kabłączki skroniowe) i okres późnego średniowiecza (jamy odpadkowe). Zebrano również skromny materiał pradziejowy ${ }^{43}$.

\section{Obszar inwestycji w przestrzeni}

zabytkowego układu wiejskiego Spycimierza

Układ przestrzenny Spycimierzanie znajdował się do niedawna w kręgu zainteresowań badaczy. M. Kulesza, zaliczając Spycimierz do miast założonych na starszym organizmie osadniczym, pominął analizę jego rozplanowania ${ }^{44}$.

4I T. Poklewski, Spicymierska włość..., s. 76-99.

42 Karta KEZAL stanowiska AZP 62-45/177.

43 A. Nierychlewska, Z. Rybacki, Opracowanie wraz ze sprawozdaniem z badań archeologicznych w Spycimierzu, gm. Uniejów, pow.poddębicki, woj. łódzkie, przeprowadzonych w 2020r. w związku z realizacją inwestycji, polegajaca na budowie ołtarza św. Julianny z Cornillon, Łódź 2020, mps w archiwum Wojewódzkiego Urzędu Ochrony Zabytków w Łodzi.

44 M. Kulesza, Morfogeneza miast na obszarze Polski Środkowej w okresie przedrozbiorowym. Dawne województwa tęczyckie i sieradzkie, Łódź 200I, s. 47. 
Archeolodzy, aktywni w XX w. na terenie Spycimierza, skupiali się na grodzisku, jego najbliższym otoczeniu oraz na użytkowanych rolniczo obszarach sąsiadujących z nawsiem, poddanych badaniom powierzchniowym ${ }^{45}$. W ostatnim czasie najwięcej uwagi zagadnieniu poświęcił T. Figlus. Stworzone przez niego opracowanie dotyczy przede wszystkim kontekstu geograficzno-osadniczego, w jakim ukształtowana została wieś. Układ przestrzenny Spycimierza jest, zdaniem Figlusa, efektem samoistnego rozwoju, postępującego od stuleci i determinowanego przez uwarunkowania przestrzenne terenu. W ten sposób ukształtowała się wielodrożnicowa forma układu ruralistycznego z blokową, nieregularną parcelacją ${ }^{46}$.

Aktualnie układ przestrzenny Spycimierza zaliczany jest do tzw. wielodrożnic. Proces jego kształtowania się może zostać częściowo prześledzony na podstawie zachowanych materiałów kartograficznych, pochodzących z XVIII w. oraz z przełomu XVIII/XIX w., a więc z pominięciem głównego okresu funkcjonowania osady (XI/XII-XVIII w.).

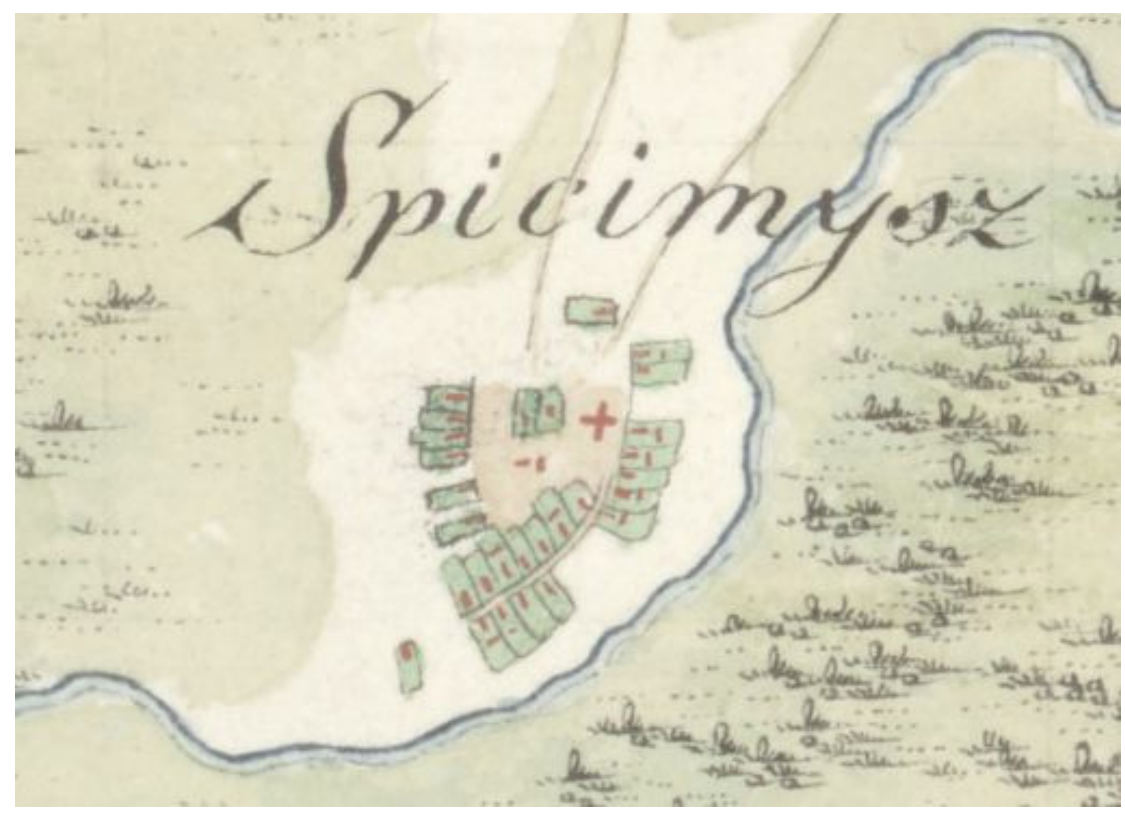

Ryc. 3. Mapa Gilly'ego z 1793 r. - otwarty układ przestrzenny Spycimierza z częściowo jeszcze niezabudowanym wnętrzem placu i początkiem parcelacji na terenie inwestycji Źródło: David Gilly, Karte von Südpreussen, I793, Staatsbibliothekzu Berlin

45 T. Poklewski, Spicymierska wtość..., s. I7-27.

46 T. Figlus, Rozwój uktadu..., s. 73-75, 90. 
Najstarsze znane przedstawienie przestrzeni Spycimierza zostało wykonane przez pruskiego kartografa Davida Gilly'ego, któremu powierzono opracowanie mapy terenów przyłączonych do Królestwa Prus po 1793 r. Malowaną akwarelami mapę sporządzono w latach 90. XVIII w. w skali I:50 ooo. Lepiej znana jest opracowana na jej podstawie mapa drukowana w skali I:I I5 000, wydana w I803 r., lecz ze względu na skalę nie zawiera ona danych dotyczących układów przestrzennych osiedli. Mapa z I793 r. przechowywana jest w Bibliotece w Berlinie ${ }^{47}$.

Uproszczony plan wsi przedstawia otwartą od północy osadę owalnicową, której zabudowę zorganizowano wzdłuż podkowiastego łuku - podstawy dwóch dróg, rozchodzących się w kierunku północnym (północny zachód i północny wschód), prowadzących do Uniejowa oraz w kierunku zachodnim - m.in. na Ewinów. W południowej części otwartego placu pierwotnego targowiska osady - istniała już wówczas zabudowa wchodząca w jego przestrzeń, zorganizowana po obu stronach drogi wkraczającej w wieś od południowego zachodu. Północna część wsi pozostawała wciąż otwarta, choć we wschodniej partii placu znajdował się kościół, a w jego obrębie istniały już pojedyncze posesje oraz zabudowa poza parcelacją, zlokalizowana w centralnej części osiedla (być może były to zabudowania handlowe w formie jatek). Do obrazu wyłaniającego się ze schematycznie zarysowanej parcelacji północnej części targowiska należy podchodzić z dużą ostrożnością, jednak może ona odpowiadać lokalizacji obszaru poddanego badaniom - posesji znajdujących się na wprost kościoła.

Wiejska zabudowa Spycimierza została oddana schematycznie, zgodnie z oznaczeniami stosowanymi przez autora mapy. Przyjmując, że symboliczne oznaczenia to wierne przedstawienie, należałoby określić zabudowę posesji skupionych wzdłuż pierzei placu i drogi (w strefie zwartej parcelacji) jako składającą się ze szczytowo zapewne ustawionych domostw położonych we frontowych częściach działek oraz zabudowań gospodarczych (prawdopodobnie wielofunkcyjnych stodół), wybudowanych w głębi podwórek i ustawionych kalenicowo. Taki model zagospodarowania parcel często powtarza się w nowożytnym osadnictwie. Zabudowa dwóch posesji położonych w obrębie placu na wprost kościoła oznaczona została odmiennie - na obu działkach znajdowały się pojedyncze budynki zlokalizowane w centralnych częściach parceli.

47 D. Gilly, Karte von Südpreussen, I793, Staatsbibliothek zu Berlin. 


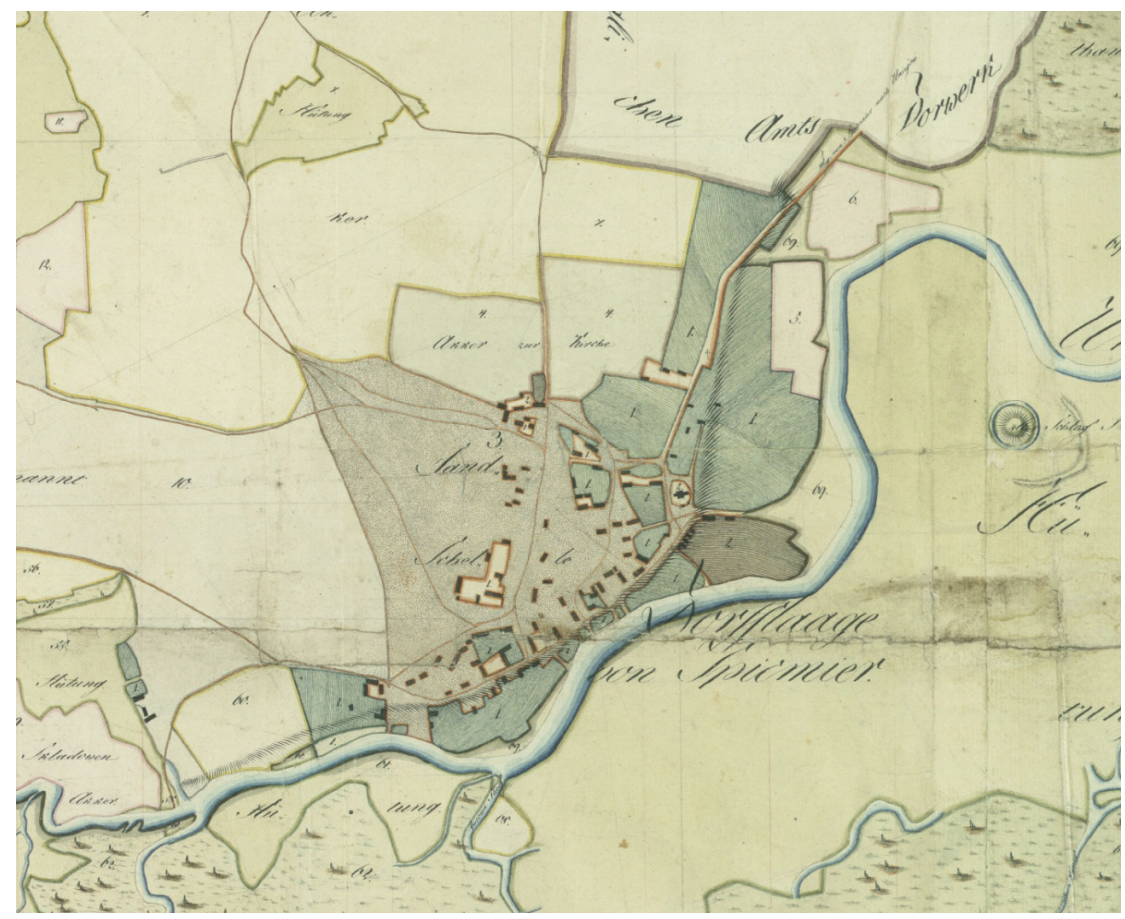

Ryc. 4. Mapa z I804 r. - układ wsi

Plan wsi Spicymierz w ekonomii Uniejów (I804 r.); AGAD - Zbiór Kartograficzny, 344-4

Odmienny charakter ma zobrazowanie układu przestrzennego wsi na mapie z I804 r. Zrezygnowano tu z przedstawienia części parcelacji, tworząc wrażenie luźnego rozmieszczenia pojedynczych zabudowań. Również tutaj zabudowa skupiona jest w południowej części wsi, po obu stronach drogi prowadzącej do Spycimierza od zachodu (południowego zachodu). Wyraźnie oznaczono skarpę terasy opadającej w dolinę rzeczną, wzdłuż której poprowadzona została wschodnia pierzeja wewnętrznego placu. W jej sąsiedztwie zlokalizowany jest kościól, położony na nieregularnej, zbliżonej do owalu działce, mieszczącej również cmentarz. Na wschód od kościoła wyszczególniono podziały parcelacyjne, w obrębie części z nich zaznaczono zabudowę biegnącą wzdłuż linii drogi. Otoczenie kościoła podzielone jest drogami o lokalnym charakterze, prowadzącymi do rzeki oraz zlokalizowanych zapewne w dolinie pastwisk i ogrodów.

Wnętrze pierwotnego targowiska było już wówczas poprzecinane drogami, poprowadzonymi również przez niezabudowane obszary centralnego placu. Kontynuowały one przebieg głównych tras opuszczających teren wsi, 
a także umożliwiały komunikację pomiędzy nimi. Zachodnia droga prowadząca w kierunku północnym była w stosunku do obecnego traktu przesunięta na zachód - przebiegała zapewne w rejonie cmentarza. Z północnej i południowej części wsi w stronę północno-zachodnią wychodziły ponadto drogi, łączące się na rozstaju położonym już poza wsią, na terenach zajętych dziś przez lasy i pola uprawne, skąd prowadziły polne drogi w kierunku zachodnim. W przestrzeni wsi podzielonej przebiegiem dróg wytyczono parcele oraz wzniesiono zabudowania, orientując je względem sieci drożnej.

Na wprost od kościoła wyraźnie oznaczone zostały parcele zamarkowane kolorem zielonym (oznaczającym ogrody). Duża działka wytyczona naprzeciw świątyni miała kształt zbliżony do nieregularnego trapezu. W jego północnej części rozciągał się (z zachodu na wschód) przejezdny dziedziniec podwórza, przy którym skupiono zabudowę. Stanowiły ją trzy budynki, wzniesione na obu skrajach dziedzińca - na wprost kościoła

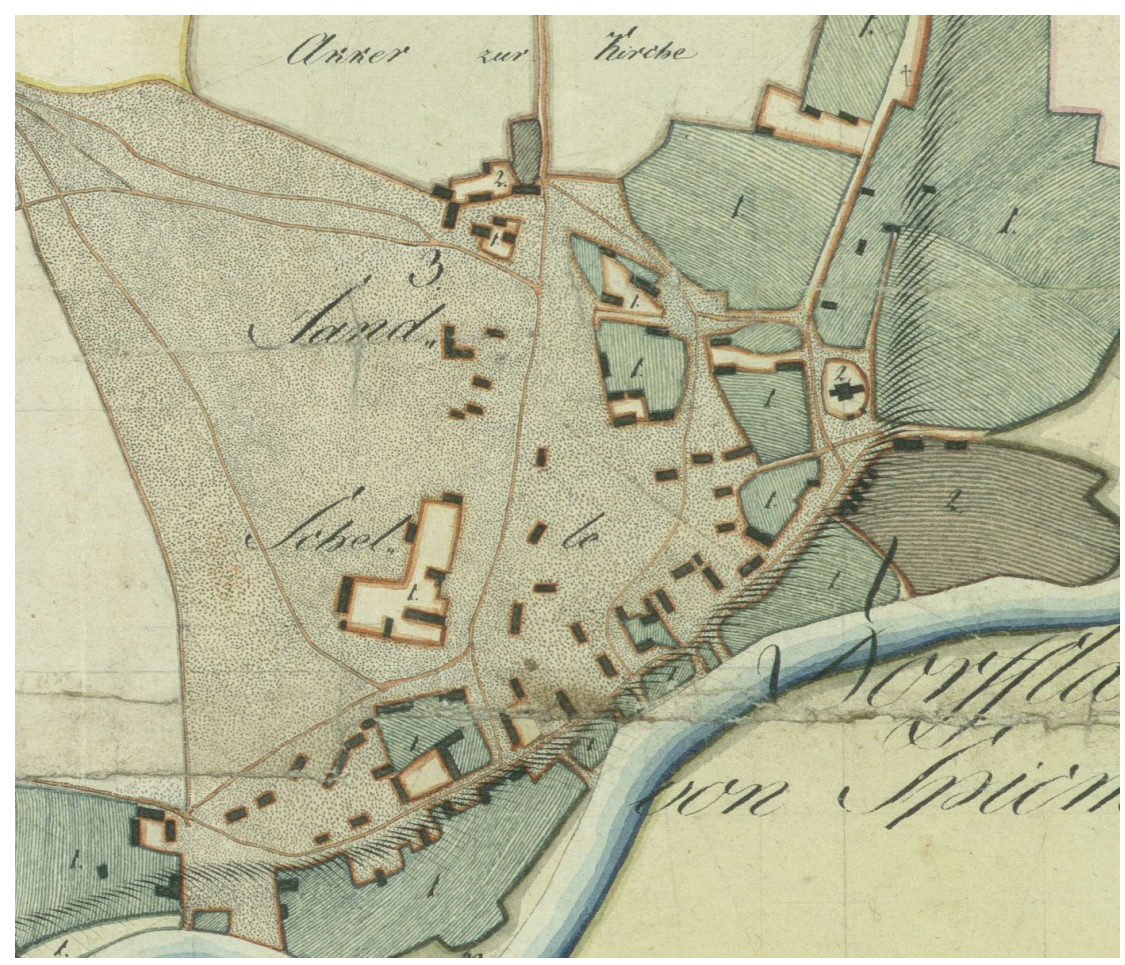

Ryc. 5. Mapa z I804 r. - zbliżenie na centrum wsi, z widoczną parcelacją obszaru na wprost kościoła (teren inwestycji), zabudową i przebiegiem dróg. Zabudowa skupiona jest w północnej części posesji

Plan wsi Spicymierz w ekonomii Uniejów (I804 r.); AGAD - Zbiór Kartograficzny, 344-4 
oraz przy zachodniej granicy działki. Obiekty te ustawione były szczytowo względem dróg, dłuższym bokiem do dziedzińca. Granice posesji nie pokrywały się z przebiegiem oznaczonych dróg - między granicami parcel a wytyczonymi drogami (zapewne gruntowymi) pozostawała niezagospodarowana przestrzeń.
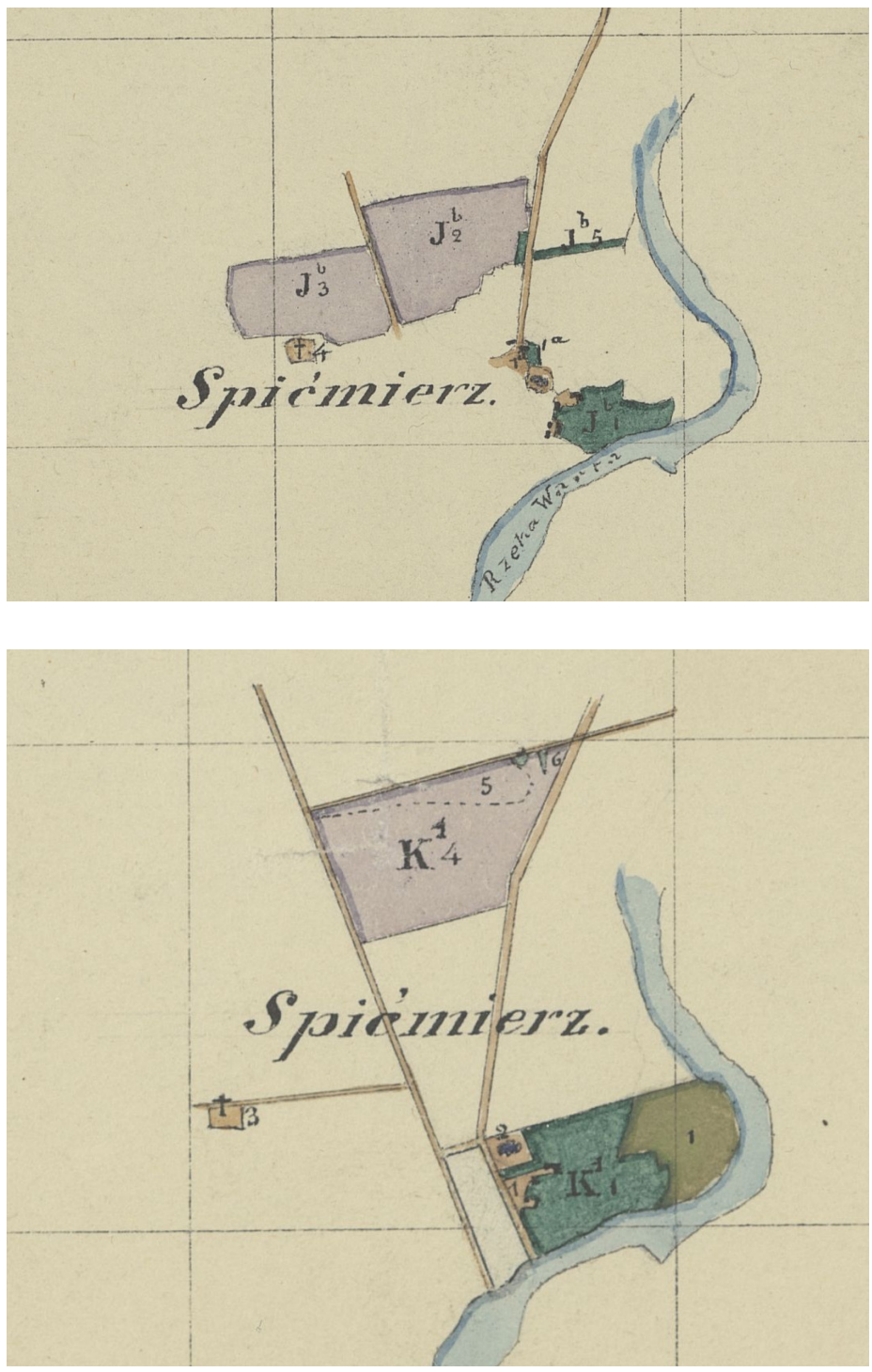

Ryc. 6. I 847 r. - mapy posiadłości probostwa w Spycimierzu

Plan gruntów probostwa we wsi Spicymierz w powiecie tureckim (I847 r.); AGAD Zbiór Kartograficzny 555-25 
Mapa gruntów probostwa „w stanie po urządzeniu” narysowana w I847 r. przedstawia wyłącznie teren posesji należących do parafii w Spycimierzu, uwzględniając ich lokalizację względem przebiegu dróg i sieci wodnej. Z mapy tej wynika, że do probostwa należały działka z kościołem, niewielka działka na północ od kościoła oraz ogród (zapewne również folwark), położony na południowy wschód od kościoła, na terenie opadającym ku rzece. Działka ta na mapie z I804 r. została oznaczona kolorem brunatnym. Źródło potwierdza lokalizację punktów odniesienia, a także dowodzi, że parcele zlokalizowane w obrębie placu na wprost kościoła nie stanowiły własności miejscowego probostwa.

Mapa z lat I845/I86I przedstawia przede wszystkim parcelację nowo wytyczonej kolonii i pomija parcelację zachodniej części „starej” wsi. Widoczny jest układ działek na północ od kościoła, skupionych wzdłuż dróg opuszczających Spycimierz w kierunku północnym. Po raz pierwszy przedstawiony został istniejący do dziś układ dróg opuszczających wieś w północną stronę, z prostą zachodnią drogą w obecnej lokalizacji (rozmierzone zostały przy tym położone wzdłuż niej posesje). Widoczny jest kościól, zlokalizowany w obrębie czworokątnego placu, oraz majątek Probostwo, przylegający do terenów kościelnych od południowego wschodu. Wewnątrz pierwotnego targowiska oznaczono pojedynczą parcelę, ciągnącą się od rozwidlenia dróg w kierunku południowym aż do koryta rzeki. Prawdopodobnie obszar ten zawiera

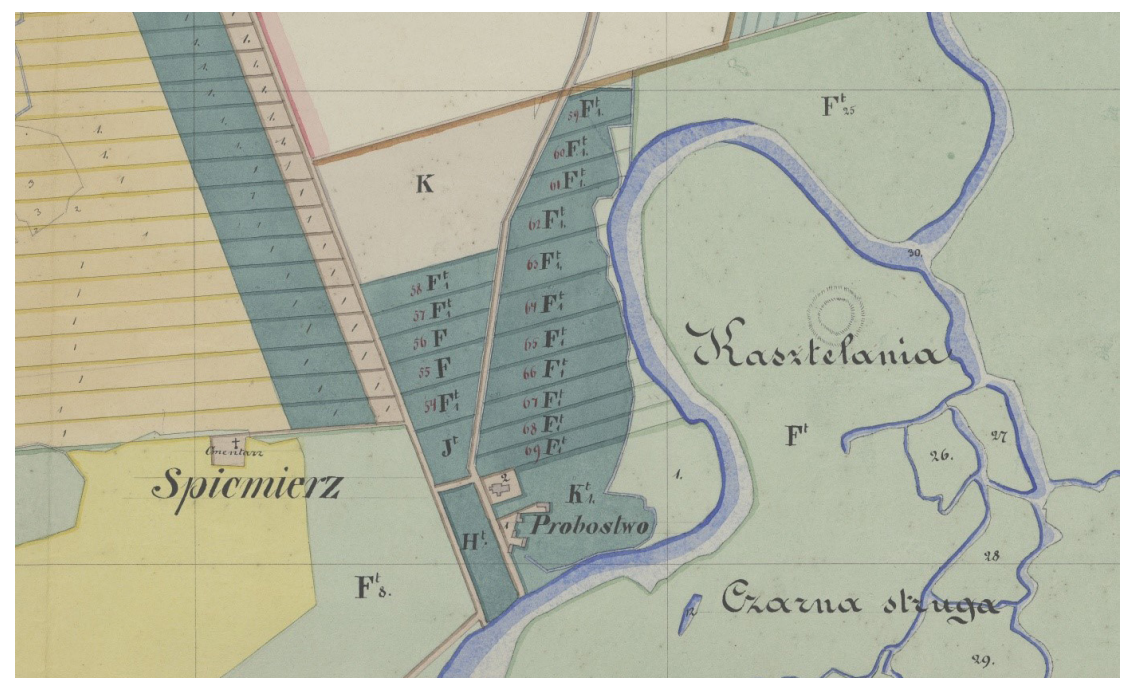

Ryc. 7. I845 r. (odrys z I86I r.) - regulacja części wsi (fragment mapy)

Plan pomiarowy kolonii Spicymierz (I86I r.); AGAD - Zbiór Kartograficzny 204-I5 
w sobie parcele opisane na podstawie wcześniejszych map. Jego północna część stanowi omawiany obszar inwestycji. Działki te oznaczono kolorem ciemnozielonym jako obszar użytkowany w charakterze ogrodów.

\section{Podsumowanie}

Osada wiejska w Spycimierzu rozwijała się zapewne już od XI-XII w. w swojej obecnej lokalizacji, oddzielona rzeką od kasztelańskiego grodu. Odgrywała ona istotną rolę, co doprowadziło zapewne do szybkiego ukształtowania się osady owalnicowej o otwartym, rozległym targowisku, w którego obrębie wybudowany został kościół parafialny. Odkryte w jego sąsiedztwie pochówki z kabłączkami skroniowymi wskazują na wczesną metrykę pierwszej świątyni oraz sepulkralną funkcję jej najbliższego otoczenia. Utrata znaczenia Spycimierza po I33I r. została pogłębiona za sprawą przemian administracyjnych, które dokonały się w okresie zjednoczenia Królestwa Polskiego przez Kazimierza Wielkiego. Dawne kasztelanie utraciły wówczas dotychczasową rangę, zaś Spycimierz znalazł się w nowo utworzonym powiecie szadkowskim. Przekazanie Spycimierza arcybiskupowi gnieźnieńskiemu pozbawiło go roli głównego centrum majątkowego wobec dynamicznego rozwoju pobliskiego Uniejowa, który otrzymał pod koniec XIII w. prawa miejskie, a następnie z inicjatywy abp. Skotnickiego wybudowano w nim zamek - obronno-rezydencjonalną siedzibę arcybiskupią. W kolejnych latach Spycimierz stanowił jedynie lokalne centrum klucza majątkowego, zarządzane przez dzierżawców. Przez pewien czas w Spycimierzu funkcjonował jeszcze gród, przekształcony w XIV w. na wzór popularnych wówczas obronnych siedzib rycerskich typu motte-and-bailey. $\mathrm{Z}$ biegiem lat jego rola podupadła, co spowodowane było skupianiem wielu funkcji administracyjnych w rękach znaczniejszych osobistości, zamieszkujących we własnych posiadłościach lub we władanych przez siebie królewszczyznach o największym znaczeniu.

W okresie przynależności do majątku arcybiskupów gnieźnieńskich w Spycimierzu zintensyfikowano działalność rolną, przeznaczając pod uprawy kolejne areały ziemi. Zapewne nie szło to jednak w parze ze wzrostem zaludnienia wsi. Przyrost demograficzny zatrzymał się w późnym średniowieczu na określonym poziomie i nie ulegał większym wahaniom aż do końca istnienia przedrozbiorowej Rzeczypospolitej. Sytuacja ta znajdowała odzwierciedlenie w powolnym rozwoju układu przestrzennego. 
Układ przestrzenny Spycimierza determinuje ukształtowanie terenu, w tym zwłaszcza zbocze stromo opadające w dolinę rzeki oraz sieć głównych dróg - przede wszystkim trakt prowadzący przez wysoczyznę wzdłuż skraju nadrzecznej doliny, z rozgałęzieniem w północnej części osiedla. Czynniki te doprowadziły do wykształcenia się podkowiastego układu zabudowy, otwartego od strony północnej, gdzie z rozległego placu - zakola głównego traktu - wyodrębniały się dwie znaczniejsze drogi prowadzące na północ. Układ ten zapewne przetrwał aż do rozbiorów, gdy został udokumentowany w kartografii.

Na mapach z przełomu XVIII i XIX w. ściślejsza parcelacja obejmowała w dalszym ciągu południową i wschodnią część wsi, z luźniej zagospodarowaną zachodnią partią. W obrębie pierwotnego targowiska stopniowo rozwijała się zabudowa, wprowadzana przede wszystkim wzdłuż północnej pierzei głównej drogi przechodzącej przez wieś. Wielodrożny układ wnętrza wsi wykształcił się w pełni na przełomie XIX-XX w., stanowiąc nawiązanie do istniejących już wcześniej dróg (zapewne gruntowych), przecinających plac w różnych kierunkach. Wewnątrz targowiska pod koniec XVIII w. znajdowały się tylko pojedyncze posesje, skupione na terenie sąsiadującym z kościołem parafialnym. W kolejnych latach rozwój parcelacji oraz zabudowy wewnątrz placu postępował już intensywniej, nowe parcele wydzielano w odniesieniu do sieci dróg wykształconych w obrębie placu.

Rozwój zagospodarowania przestrzennego wnętrza placu jest ściśle związany z historią posesji poddanych bieżącej inwestycji. Pod koniec XVIII w. znajdowały się tu pojedyncze parcele o przypuszczalnie jednodworczym charakterze. W początkach XIX stulecia teren inwestycji zajmowała działka o nieregularnym obrysie, w północnej części przecięta przez równoleżnikowo przebiegający dziedziniec, przy którym znajdowały się zabudowania. Zapewne w drugiej połowie XIX w. wprowadzony został zbliżony do dzisiejszego, bardziej wyrównany obrys kwartału zabudowy, który wciąż jednak ciąży ku układowi widocznemu na mapach z początku XIX stulecia. Historyczne przekształcenia parcelacji omawianego obszaru dotyczą przesunięć linii granic działek i wyznaczających je ogrodzeń, przebiegających niekiedy nieregularnie (łukowato) i zmieniających ukształtowanie na poszczególnych odcinkach. W obrębie obszaru inwestycji mogły przebiegać również drogi przecinające wewnętrzny plac wsi i oznaczone na mapach z I poł. XIX w. Osobne zagadnienie stanowią niewątpliwie przekształcenia zagospodarowania wnętrza posesji, 
zawierające budynki, podwórze, ogród i najprawdopodobniej również zagrody dla zwierząt czy urządzenia sanitarne, takie jak studnie. Duży wpływ na użytkowanie tej przestrzeni w długotrwałym okresie poprzedzającym wykonanie znanych nam źródeł kartograficznych (przed końcem XVIII w.) miało zapewne bliskie sąsiedztwo uczęszczanego szlaku komunikacyjnego prowadzącego do Uniejowa, bezpośrednie usytuowanie kościoła wraz z otaczającym go cmentarzem i specyfika wewnętrznego placu wsi owalnicowej, zwyczajowo użytkowanego jako pastwisko i plac targowy. Istniejący na tym terenie do dziś budynek szkoły wzniesiony został przed drugą wojną światową, lecz szkoła w Spycimierzu ma dłuższą historię, sięgającą co najmniej I połowy XIX stulecia ${ }^{4}$.

$\mathrm{Na}$ podstawie przeprowadzonych analiz można zaproponować następujące rozwarstwienie chronologiczne przekształceń omawianego obszaru planowanej inwestycji. Ustalenia te powinny zostać zweryfikowane badaniami archeologicznymi.

Faza 0 - prawdopodobnie omawiany obszar poddany był infiltracji osadnictwa pradziejowego, potwierdzonego podczas prowadzonych na terenie gminy Spycimierz badań archeologicznych.

Faza I (XII-XVIII w.) - obszar posesji funkcjonował od początków średniowiecznego osadnictwa wiejskiego jako część wewnętrznego placu wiejskiego, użytkowanego w charakterze placu targowego i pastwiska, w bezpośrednim sąsiedztwie kościoła, cmentarza i głównej drogi prowadzącej w kierunku Uniejowa. Brak danych nie neguje możliwości istnienia tu zabudowy targowej lub wcześniejszej parcelacji, jak również funkcjonowania dróg (lub ścieżek) znanych z późniejszego okresu.

Faza II (2 poł. XVIII w.) - potwierdzona obecność parcel - ogrodów o przypuszczalnie jednodworczej zabudowie.

Faza III (I poł. XIX w.) - w północnej części posesji wydzielony został przejezdny dziedziniec, wzdłuż którego znajdowały się zabudowania; parcela posiadała wówczas nieregularny obrys i otoczona była siecią dróg. Układ ten tylko częściowo pokrywał się z dzisiejszym (uregulowanym) podziałem przestrzeni wsi, w stosunku do późniejszej sytuacji możliwe są więc jego przesunięcia.

Faza IV ( 2 poł. XIX w.) - na omawianym terenie zaprojektowany został regularny, czworokątny obrys kwartału zabudowy, obejmujący obszerny

48 Archiwum Państwowe w Kaliszu: Naczelnik Powiatu Kaliskiego I4/346; Archiwum

Państwowe w Łodzi: Dyrekcja Szkolna Kaliska 276, I526. 
pas terenu. Regulację udało się zrealizować tylko częściowo, gdyż niezbyt dokładne XIX-wieczne mapy uniemożliwiają jednak stwierdzenie, jaki obszar posesji znalazł się poza jej dawnymi granicami lub też w jakim stopniu utrwalone granice działki objęły wcześniejszą przestrzeń publiczną.

Faza V (XIX/XX w. - do czasów współczesnych) - w tym okresie utrwalił się obecny stan zabudowy posesji, zajętej przez szkołę i jej zaplecze, a w części południowej - wybudowany podczas drugiej wojny światowej bunkier. W stosunku do kwartału uregulowanego (zaprojektowanego) w I845 r. posesja okrojona została o część południowo-zachodnią, poddaną podziałom parcelacyjnym.

\section{Bibliografia}

\section{Literatura}

Chlebowski B., Sulimierski F., Walewski W., Stownik Geograficzny Królestwa Polskiego i innych krajów stowiańskich, t. II, Warszawa I89o.

Figlus T., Rozwój uktadu ruralistycznego Spycimierza na tle dziejów osadnictwa w świetle badań geograficzno-historycznych i archeologicznych, „Biuletyn Uniejowski” 20I5, t. 4, s. 73-94.

Grabarczyk T., Kowalska-Pietrzak A., Szymczak J., Uniejowskie strony: karty z przeszłości odległej, nieznanej i bliskiej gminy Uniejów, ŁódźUniejów 2008,

Jakimowicz R., Sprawozdanie z dziatalności Państwowego Konserwatora Zabytków Przedhistorycznych Okręgu Warszawskiego za rok 1923, „Wiadomości Archeologiczne” 1925, t. IX, z. 3-4, s. 305-33I.

Kamińska J., Grody wczesnośredniowieczne ziem Polski środkowej na tle osadnictwa, „Acta Archaeologica Universitatis Lodziensis” 1953, nr 2.

Kietlińska A., Dąbrowska T., Cmentarzysko z okresu wptywów rzymskich we wsi Spicimierz, pow. Turek, „Materiały Starożytne” 1963, t. IX, s. I43-252.

Kulesza M., Morfogeneza miast na obszarze Polski Środkowej w okresie przedrozbiorowym. Dawne województwa tęczyckie i sieradzkie, Łódź $200 \mathrm{I}$.

Nadolski A., Spicymierz nad Wartą, średniowieczny zespót osadniczy, „Archeologia Polski” 1966, t. IO, z. 2, s. 70I-712.

Poklewski T., Spicymierska wtość grodowa w średniowieczu. Obraz gospodarczy, Łódź 1975. 
Rosin R., Warunki naturalne, drogi ladowe i rozwój terytorialno-administracyjny, [w:] J. Śmiałowski (red.), Szkice z dziejów Sieradzkiego, Łódź 1977, s. I2-30.

Rosin R., Zajączkowski S.M., Osadnictwo i stosunki własnościowe sieradzkiego na przetomie późnego średniowiecza i czasów nowożytnych, [w:] T.J. Horbacz, L.Kajzer (red.), Między pótnoca a potudniem. Sieradzkie i wieluńskie w późnym średniowieczu i czasach nowożytnych. Materiaty z sesji naukowej w Kościerzynie koło Sieradza (4-6 grudnia I99I r.), Sieradz 1993, s. 3I-47

Różańska W., Cmentarzysko tużyckie z mtodszego okresu halsztackiego w Spicymierzu, pow. Turek, „Materiały Starożytne” 1958, t. IV, s. I45-156.

Rutkowski H., Granice państwowych jednostek terytorialnych, [w:] Atlas Historyczny Polski. Województwo sieradzkie i województwo tęczyckie w drugiej połowie XVI wieku, cz. II, Komentarz, indeksy, Warszawa 1998, s. 26-29

Sikora J., Grodziska wczesnośredniowieczne Polski Centralnej. Archeologiczne badania nieinwazyjne z lat 2013-2016, Łódź 2017.

Skoiński J., Spicimierz. Gród i kasztelania. Szkic historyczny, Łódź 1936.

Szymczakowa A., Nobiles Siradienses. Rody Porajów, Pomianów, Gryfów, Kopaczów i Pobogów, Łódź 2011.

Wąsicki J., Ziemie polskie pod zaborem pruskim. Prusy Południowe 1793-I806, Studium historyczno-prawne, Wrocław 1957.

Zajaczkowski S., Zajączkowski S.M., Materiaty do stownika geograficzno-historycznego dawnych ziem tęczyckiej i sieradzkiej do I40o roku, cz. II, Łódź 1970.

\section{Opracowania niepublikowane}

Karta KEZAL stanowiska AZP 62-45/I77, Wojewódzki Urząd Ochrony Zabytków w Łodzi.

Nierychlewska A., Rybacki Z., Opracowanie wraz ze sprawozdaniem z badań archeologicznych w Spycimierzu, gm. Uniejów, pow. poddębicki, woj. tódzkie, przeprowadzonych $w 2020$ r. $w$ zwiazku z realizacja inwestycji polegająca na budowie ottarza św. Julianny z Cornillon, Łódź 2020, mps w archiwum Wojewódzkiego Urzędu Ochrony Zabytków w Łodzi.

\section{Źródła pisane, wydane drukiem lub udostępniane cyfrowo}

Gall Anonim, Cronica et gesta ducum sive principum Polonorum, wyd. K. Maleczyński, Kraków 1952. 
Herby rycerstwa polskiego przez Bartosza Paprockiego zebrane $i$ wydane r.p. I584, wyd. K.J. Turowski, Kraków I858 (udostępnione w Wielkopolskiej Bibliotece Cyfrowej https://www.wbc.poznan.pl/dlibra/publication/3II64/ edition/48455/content).

Kodeks Dyplomatyczny Wielkopolski, seria I, I/II, II, [online] https://www. wbc.poznan.pl/ [dostęp: 22.03.2021].

Łaski J., Liber beneficiorum archidiecezji gnieźnieńskiej, t. I obejmujący archidiakonaty: gnieźnieński, uniejowski i kurzelowski: z poręki Towarzystwa Przyjaciół Nauk Poznańskiego, podług kodeksów rękopiśmiennych Archiwum Gnieźnieńskiego i Kaliskiego, wyd. J. Korytkowski, Gniezno I880.

Tabela miast, wsi, osad Królestwa Polskiego z wyrażeniem ich położenia i ludności, alfabetycznie ułożona w Biurze Komisji Rzadowej Spraw Wewnętrznych i Policji, t. 2, Warszawa 1827, [online] https://www.wbc.poznan.pl/dlibra/ show-content/publication/edition/IIOII7?id=IIOII7 [dostęp: 20.03.202I].

Taryfa podymnego z 1775 r., Verzeichniß aller adelichen, geistlichen und königlichen Oertern in Polen, nach den Woiwodschaften und Districten, und mit Bemerkung der Anzahl der Rauchfänge in jedem Orte, „Magazin für die neue Historie und Geographie” 1788, t. 22, [online] https://books. google.pl/books?id=X41OAAAAcAAJ\&printsec=frontcover\& $\mathrm{hl}=\mathrm{pl} \# \mathrm{v}=$ onepage\&q\&f=false [dostęp: 20.03.202I].

\section{Źródła pisane niepublikowane}

Archiwum Narodowe w Krakowie: Zbiór Zygmunta Glogera 2/233, 2/324. Archiwum Państwowe w Kaliszu: Naczelnik Powiatu Kaliskiego 14/346. Archiwum Państwowe w Łodzi: Urząd Gubernialny Kaliski do Spraw Włościańskich III7, III8, III8a, II20, 3134; Dyrekcja Szkolna Kaliska 276, I526.

Archiwum Państwowe w Łodzi, oddział w Sieradzu: Powiatowa Komisja Sprawiedliwości w Sieradzu 519.

\section{Mapy}

\section{Mapy drukowane}

AMS M751, M753 Poland, M752 East Prussia I:50 o00, 292I IV Uniejów (1963 r.), http://maps.mapywig.org/m/ALLIED_maps/series/AMS_M752-753_050K// AMS_M75I_POLAND_5oK_292I_IV_UNIEJOW_ed_I_I963.jpg [dostęp: 21.03.2021]. 
Mapa Administracyjna Rzeczypospolitej Polskiej I:300 ooo, ark. 24 (64), 1937 r., http://maps.mapywig.org/m/WIG_maps/series/30oK_admin/ MARP_24_LODZ_1937.jpg [dostęp: 21.03.202I].

Mapa Szczegótowa Polski, Oberkommando des Heeres, P4I S27 C (4I27 C) Brückstädt (Unjejow), http://maps.mapywig.org/m/WIG_maps/ series/O25K_german/4I27_C_Brueckstaedt_(Unjejow)_XII.I944.jpg [dostęp: 21.03.2021].

Nakęski K., Mapa Królestwa Polskiego z oznaczeniem miast, osad, wsi, komór, kolei, dróg bitych, traktów pocztowych i rzek (1913 r.), http://maps.mapywig. org/m/Polish_maps/various/Mapa_Krol_Pol_(auto)_504K_19i3/ Mapa_Krolestwa_Polskiego_[auto]_504K_Karta_II_LODZ_caI9I3_ BCUWr-c8200037499-0029.jpg [dostęp: 21.03.202I].

Übersichtskarte von Mitteleuropa I893 B, Piotrków Q52, (1909 r.) http:// maps.mapywig.org/m/German_maps/series/30oK_UvM/UvM_ Piotrkow_1909.jpg [dostęp: 21.03.2021].

\section{Zabytkowe mapy topograficzne}

Gilly D., Karte von Südpreussen, I793, Staatsbibliothekzu Berlin.

Gilly D., Spezialkarte von Südpreussen, I813, Staatsbibliothekzu Berlin.

Kolberg J. , Atlas Królestwa Polskiego, Warszawa I827 (Biblioteka Narodowa, https://polona.pl/item/atlas-krolestwa-polskiego-atlas-du-royaume-depologne,NDcwMDgwNjE) [dostęp: 20.03.202I].

Mapa Kwatermistrzostwa, ark. Io, kol. II, sek. IV Łęczyca I843 r., http://maps. mapywig.org/m/Polish_maps/series/ı26K_Mapa_Kwatermistrzostwa/ TKKPI26K_ark-IO_Kol_II_Sek_IV_\%C5\%81\%C4\%99czyca_6oodpi_ BCPolona.jpg [dostęp: 21.03.2021].

Perthées de K., Mappa Szczegulna Woiewodztwa Łęczyckiego, I793 r. (AGAD, AK 96, Zb. SA I2).

Archiwalne plany Spycimierza kartografia wykorzystana w opracowaniu

Plan gruntów probostwa we wsi Spicymierz w powiecie tureckim (I847 r.), AGAD - ZK $555^{-25}$.

Plan pomiarowy kolonii Spicymierz (I845-I86I r.), AGAD - ZK 204-I5.

Plan wsi Spicymierz w ekonomii Uniejów (I804 r.), AGAD - ZK, 344-4. 


\section{A short history of topographic changes in a church-adjoining part of Spycimierz (Uniejów municipality)}

SUMMARY | The aim of this study is to highlight the character of spatial changes that took place over centuries on estates located in front of the church (plot no 406) before the present form of spatial development on this site. This is relevant to archaeological work carried out in 202I before the start of the construction of the Historical and Cultural Centre "Spycimierskie Boże Ciało" (Spycimierz Corpus Christi). The conclusions were formulated after identifying, selecting and analysing relevant source materials. A synthesis of collected information resulted in a proposal of periodization of topographic changes in the analysed area, identifying five chronological phases.

K EYWOR D S | Spycimierz, Uniejów municipality, Corpus Christi, archaeological research

| Informacje o artykule: przyjęto - 3I maja 202I; zaakceptowano - 28 czerwca 202I 